\title{
ФРАЗЕОЛОГИЗМЫ С КОМПОНЕНТОМ САПОГ
}

\author{
Рыбакина Анастасия Сергеевна \\ студент \\ Брянский Государственный Университет \\ имени академика И.Г. Петровского
}

\begin{abstract}
Аннотация: в статье рассмотрены фразеологизмы с компонентом сапог на примере немецкого и русского языков. Как показывает материал, искомые фразеологизмы является транслятором того, какой объём культурной информации носители языка подразумевают, используя компонент сапог в устойчивых оборотах языка. Сапог - идеальная пара; бедность и даже оплошность человека.
\end{abstract}

Ключевые слова: фразеологизм, компонент сапог, значение, ассоциация, оценка.

\section{PHRASEOLOGY WITH A COMPONENT OF BOOTS}

\section{Rybakina Anastasia Sergeevna}

Abstract: the article considers phraseological units with a component of boots on the example of German and Russian languages. As the material shows, the required phraseological units are a translator of how much cultural information native speakers mean by using the boots component in stable language turns. The boot is the perfect pair; poverty and even a human oversight.

Key words: phraseology, component of boots, meaning, association, evaluation.

«Сапог - это вид обуви с высоким голенищем.» [1]

На первый взгляд обычный сапог для многих народов имеет разное значение в том или ином фразеологизме (ФЕ). С одной стороны он может нести смысл оплошности, с другой бедности или даже идеальную пару. Рассмотрим фразеологизмы с компонентом сапог в русском и немецком языках.

Один из самых романтичных ФЕ с компонентом сапог звучит следующим образом Два сапога - пара[2], однако существует и более длинная версия данного фразеологизма Два сапога - пара, да оба на левую ногу надеты [2]. 
Второй ФЕ можно считать фольклорным, так как в большинства источниках распространена именно краткая версия. Сапоги - это пара, которая состоят в браке. С точки зрения окружающих они подходят друг другу по своим повадкам или привычкам. Вторая часть показывает нам, что они для общества «неправильные» оба на левую ногу надеты. То есть для большинства людей они могут совершать сумасшедшие поступки, однако в их семейном кругу они считаются нормальными. Вторая часть особенно дополняет первую часть фразеологизма, показывая, насколько пара супругов может подходить друг другу. Данный ФЕ используется с иронией, для того чтобы показать схожесть двух людей. В немецком языке Das sind zwei Paar Stiefel (букв.: это два сапога пара) [3], на первый взгляд схож с краткой версии фразеологизма в русской языке, однако это не так. Используя этот разговорный поворот, немцы подразумевают, что две вещи совершенно разные и не похожи друг на друга. Например, если человек опаздывает, потому что сажает сына в кроватку, в то время как его коллега регулярно опаздывает только потому, что не встает с постели, то это, два canoza napa [4]. Мы явно можем видеть, что на первый взгляд схожие фразеологизмы могут иметь абсолютное противоположное значение. Поэтому важно помнить, что один по звучанию ФЕ может иметь разные значения в различных языках.

Значение оплошности или расторопности с компонентом сапог мы можем увидеть в русских фразеологизмах Сапожник без сапог, а в доме гончара не найдешь крепкой посуды [2], Сапожник без сапог, а у плотника окна без наличников [2]. Данные ФЕ можно рассматривать с нескольких сторон. С одной стороны человек может быть занят своим делом настолько, что ему некогда уделить себе время. Он работает и днем и ночью, чтобы прокормить свою семью. Данный пример ярко описывает жизнь сапожников во все времена. Однако хоть они и жили при царях, им платили очень мало. Именно поэтому они часто жили очень убого. Подтверждение данной мысли мы можем видеть в книге И.А. Слонова „Из жизни торговой Москвы“, вышедшей в 1914 году, где были, так называемые „кимряки“. Кимряки - это деревенские башмачники, приезжавшие осенью из села Кимр Тверской губернии в Москву работать до Пасхи. Автор пишет свое наблюдение за этими людьми. Он говорит, что они всегда останавливались в грязных и сырых трущобах на Болоте (так называлась местность, где летом происходил большой торг ягодами и фруктами). Кимряки были люди честные и трудолюбивые, но бедные, так как их работа (они большею частью шили дамские теплые плисовые сапоги на шленке) 
оплачивалась очень скудно, и поэтому они жили тесно и грязно. Бывало, в шутку спросишь кимряка: „Где ты остановился?“ Он серьезно отвечает: „На болоте“. — „Сколько занимаешь?“ — „Полсвета“. Слово „полсвета“ означало половину окна, для этого комната с одним окном перегораживалась тонкой деревянной перегородкой на две равные части, в каждой половине помещался хозяйчик с тремя - пятью мастеровыми. [5] С другой стороны данные фразеологизмы могут говорить и об оплошности сапожника. Например, люди, которые пытаются научить чему-то, чем сами не владеют. То есть сапожник пытается научить делать сапоги, хоть сам и не знает, как это делать. Во второй части фразеологизма хоть и меняется профессия человека, но мысль остается такая же. Человек пытается научить тому, чем сам не владеет. Немецкий ФЕ Ein Schuster, der schlechte Stiefel macht, kommt in die Hölle.(букв.: сапожник, который делает плохие сапоги, попадает в ад) [3]. Данный ФЕ можно сопоставить со вторым пояснением русского фразеологизма, он несет значение оплошности человека. Однако можно увидеть насколько немцы негативно, можно сказать даже с ненавистью относятся к данной проблеме. Если человек делает некачественные вещи, ему нужно попасть в ад. На самом деле данный фразеологизм выглядит для русского понимания немного жутко. Ведь немцы можно сказать почти проклинают сапожника за плохие сапоги. Конечно, можно и понять данный ФЕ, если представить ситуацию, когда обувь неудобна при носки или развалилась посреди дороги. Неприятно, что на первый взгляд обычный атрибут гардероба сделан некачественно. Возможно, однажды сапоги поставили в неудобную ситуацию человека, вследствие чего он проклинал сапожника, который сделал данную обувь.

Сапоги являлись неотъемлемым атрибутом любого человека. Поэтому в мире существуют разные фразеологизмы с компонентом сапог. Например, ФЕ с идеей бесполезности. В русском языке ФЕ Сапоги смазаны и дыры замазаньг[2], а в немецком Alte Stiefeln bedürfen viel Schmierens (букв.: старые сапоги требуют много смазки)[3]. Данные фразеологизмы схожи. Чтобы лучше понять, рассмотрим подробнее виды сапог, которые раньше делали сапожники. Это были личные и смазные сапоги. Личные шились из кожи лицевой стороной наружу, а смазные - наоборот. Личные сапоги можно было начистить ваксой до зеркального блеска, но вакса (или гуталин) снаружи на гладкой поверхности удерживались слабо. Сапоги быстро теряли вид и, главное, водонепроницаемость. В отличие от них смазные пропитывали снаружи салом или дегтем, смазка проникала глубоко внутрь кожи, и она долго оставалась 
сохранной. То есть, смазные сапоги были водостойкими и удобные, но с возрастом появлялись сквозные дыры. Вследствие чего они пропускали влагу внутрь. Конечно, внешний вид важен, однако качество продукта важнее. Как бы долго человек не носил сапоги, но приходит время и появляются дыры, которые нужно замазывать. А это значит, что мы будем использовать большое количество смазки. Можно заметить, что в немецком ФЕ используется слово viel много. В немецком языке viel используется для обозначения неисчисляемых предметов. То есть, количество смазки настолько много, что нельзя и представить. Сапоги, которые имеют дыры, уже не влагостойкие. Можно сказать, что они становятся бесполезными для использования.

Немецкий ФЕ Er fährt hinein wie der Bauer in die Stiefeln (букв.: он въезжает внутрь, как крестьянин в сапогах) [3]. Der Bauer переводиться как крестьянин [6]. Если посмотреть в семантику слова, то можно обнаружить, что крестьянин и бедный стоят рядом. То есть, немцы ассоциируют два слова между собой и раньше могли использовать их как синонимы. В данной ФЕ употребляется именно значение бедный. Это означало, что у человека не было денег, чтобы купить качественную обувь. Когда он прибывал, например, в город, выглядел как бедняк. Похожую мысль несет и русский ФЕ Сам в canozax, а след босиком [2]. Раньше шилась обувь из кожи, но при этом у нее не было подошвы. Такую обувь использовали бедные слои общества. Также русский ФЕ имеет еще одну трактовку. Он может нести хитрость. Люди могли приукрасить действительность своих слов и вести человека в заблуждение. Они приукрашивали до такой степени, что собеседник не мог вывести обманщика на чистую воду. По сути человек говорил правду, однако местами мог изменить или умолчать малую часть действительности. В итоге собеседник не мог это оспорить и проигрывал обманщику. Как пример можно привести армянскую сказку «Мастер на восемь шапок» [7]. Суть сказки в том, что «хитрый» шапочник принял заказ от «жадного» мужчины сшить из одного куска овчины целых восемь шапок. Важно заметить, что овчина была рассчитана на 1 нормальную шапку. Шапочник взял деньги и через неделю выполнил заказ. Вследствие жадности заказчика, были сшиты 8 маленьких шапочек, но они были настолько маленькими, что можно было надеть только на яблоко. Своей хитростью он проучил жадного заказчика. Шапочник принял заказ, однако не уточнил, а точнее умолчал правду, что шапочки получаться очень маленькими. После завершения работы заказчик забрал свои 8 шапок и не мог придраться к мастеру. Хитрость сработала из-за невнимательности жадного человека, если 
бы он более детально разобрался в сущности производства товара, он бы не был обманут.

Существуют фразеологизмы, где сапог и дело связаны. Немецкий $\Phi \mathrm{E} W e r$ keinen Stiefel vertragen kann, der ist kein braver Mann (букв.: кто не может вынести сапог, тот не бравый человек) [8, с. 561]. Сапог можно трактовать как дело. То есть, если человек не может выдержать какое-то испытание, значит, что он не мужественен. Храбрый человек не будет бояться испытаний и будет с достоинством носить свои сапоги. Русский ФЕ Это дело не сапог: с ноги не скинешь [2]. Дело настолько серьезное, что его как обычный сапог нельзя скинут. В русском языке дело непростое и сложно выполнимо, в то время как в немецком наоборот оно может быть очень простым, можно сказать элементарным.

Русский ФЕ Взял черт Ваньку - возьми и сапоги [2]. Ванька в русском языке используется активно в различных ФЕ. Конечно, данные фразеологизмы приживаются в народе настолько сильно, что они могут использоваться и в повседневной жизни. Ванькой могут назвать маленького мальчика. Если рассуждать с этой точки зрения, то если взрослый человек берет ребенка, тогда он должен с собой брать запасную одежду и обувь. Дети бывают очень подвижны и для них дело нескольких минут, если за ними пристально не следить. Поэтому важно брать из обуви именно сапоги, ведь они не пропускают влагу, следовательно, ребенок не заболеет. То есть, сапоги - это запасной план, на случай, если что-то случиться с первоначальным. Но судя по тому, что присутствуют слова черт и Ванька, сапогами скорее всего воспользуются. В немецком языке Wenn die Kinderschuhe zerbrochen sind, legt man Stiefel an (букв.: если детская обувь сломана, надень сапоги) [3]. На первый взгляд, мы можем увидеть, что данный ФЕ - это совет для взрослых, которые заботятся о ребенке. Однако речь в данном языке может идти и о запасном плане. Если чтото случилось с детской обувью, ты можешь надеть сапоги и продолжить свою работу. Не нужно беспокоиться, что все будет потеряно бесповоротно.

Изучив данные фразеологизмы, мы можем прийти к выводу, что в немецком и русском народе лексема сапог употребляется в значении идеальная пара, оплошность и бедность. Важно отметить, что компонент сапог употребляется во многих немецких и русских фразеологизмах. И значения ФЕ, которые передают те или иные народы, схожи друг с другом. 


\section{Список литературы}

1. Словарь [Электронный ресурс]. - Режим доступа: https://ru.wiktionary.org/wiki/сапог - (дата обращения: 18.01.22).

2. Русские фразеологизмы [Электронный ресурс]. - Режим доступа: http://igra1.com/poslovicy-pro/poslovicy-pro-sapogi.htm - (дата обращения: 18.01.22).

3. Немецкие фразеологизмы [Электронный ресурс]. - Режим доступа: https://www.sprichwoerter.net/suche/?searchword=stiefel\&option=com_search\&Item id=45\&searchphrase $=$ exact\&ordering=newest - (дата обращения: 18.01.22).

4. Немецкий фразеологизм [Электронный ресурс]. - Режим доступа: https://1703.slovaronline.com/51581-das-sind-zwei-paar-stiefel- (дата обращения: 18.01.22).

5. Профессия сапожник [Электронный ресурс]. - Режим доступа: https://zen.yandex.ru/media/id/60d069718532537fcc5b15b3/sapojniki-vdorevoliucionnoi-rossii-ili-professiia-vostrebovannaia-vo-vse-vremena611620441bb82e33efdafda9- (дата обращения: 18.01.22).

6. Цитата [Электронный ресурс]. - Режим доступа: https://www.gutzitiert.de/zitat_autor_sprichwort_thema_bauer_zitat_25306.html(дата обращения: 18.01.22).

7. Сказка [Электронный pecypc]. - Режим доступа: https://skazki.rustih.ru/master-na-vosem-shapok/- (дата обращения: 18.01.22).

8. Sprichwörterlexikon: Sprichwörter u. sprichwörtl. Ausdrücke aus dt. Sammlungen vom 16. Jh. bis zur Gegenwart / Horst u. Annelies Beyer. - 4., unveränd. Aufl. - Leipzig : Bibliographisches Institut, 1988. - 712 S. : 204 I11. 